\title{
清 酒の褐変
}

清酒の褐変にはいくつかの型が知られているが，そのうち暗所で

貯蔵してもすべての清酒に共通してみられる褐変現象がある。この

現象は清酒の熟成之密接な関係があると考えられている。

本稿は清酒の褐变現象の定量的な扱い方解説したものであり,

複雑な清酒の熟成機構の研究を進めるとき, 有力な手掛かりを与え

てくれることと思う。

（編集部）

新しく䤑造された清酒は, 数か月間貯蔵して香味の熟 成を行なって出荷されるのが普通である。貯蔵期間が適 当な場合には調和のとれた香味の彆品が得られるが，不 適当であると未熟あるいは過熟の製品となる。経験的に 熟成の速さは夏季に大きく，冬季に小さいことが知られ ているが，また，夏前にすで完熟する清酒もあれば， 秋になってはじめて完熟する清酒もある。すなわち, 熟 成のための最適眝蔵期間は貯蔵温度によって变わると同 時に, 清酒自身の組成に上っても変わるようである。し たがって, 熟成のための貯蔵条件の決定はかなり難しい ことであり，また，最適熟度の製品を調製しても，消費 までの期間が長いと, 過熟状態に移行するという熟度の 安定性の問題もある。このような問題を克服して, 熟度 についての適切な品質管理を行ならためには, 貯蔵条件

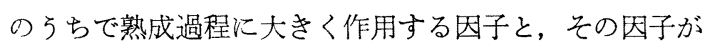
作用する方式を明らかにして，清酒ごとにその熟成しや すさの程度を見積るための方法を確立することが必要で ある。しかし, 清酒の熟度は元来きわめて官能的な評価 であって, その計量が困難であり，そのために貯蔵条件 や組成との関係を定量的に検討することはほとんどなさ れなかった。

一方, 清酒を貯蔵すると必ず多少の色の增加が扣こる ことが古くから知られている。この色の増加は, 普通の 熟成条件程度の貯蔵ではきわめて軽微でめって, 製品の 美観にはほとんど影響がない汪どであるが，過熟状態ま でくると，かなりな着色度を示すようになる。このため に, 清酒の着色を, 漠然とではあるが, 過熟による香味 の少化と関連付ける意識が働き, 着色を忌避する一般的 な傾向が生じてきている。このように貯蔵中に色が濃く なるといら現象は, 食品全般を通じて普通にみられるこ
とで，いわゆる褐変現象に属するものである。ただ清酒 の場合は, これが稀薄溶液系であるために, 一般の食品 の場合に比較して褐変程度がかなり低いという特徴があ る。この清酒の褐変速度は温度とともに著しく增加する こと, 扣よび清酒の種類によっても差異があることが認 められ，これらの傾向が見掛上香味の熟成の速さと平行 すると考えられている。このために, 清酒の褐変現象を 熟成過程に対する一つの指標として用い上らといら試み が行なわれるよらになってきた1 4)。

熟度とちがって, 褐変は色の增加であって定量的な取 扱いが可能である。したがって, 褐变举動を定量的に検 討することは, 熟成の過程を定量的に検討するための有 力な手掛かりとなるものと思われる。このような見地か ら筆者らは清酒の褐変様式を検討してきたが，その結果， 清酒の褐变性を眝蔵条件拈上び清酒組成の関数として定 量的に取报らための一つの方式を提案するに至った ${ }^{5 \sim 7)}$ 。 以下にその内容を略述し, 褐变と熟成との関連について 考察を行なうことにする。

\section{清酒の褐変経過の特徵と褐変性の表示}

褐変経過を追跡するためには, 褐变によって增加する 色の濃さを測定しなければならない。清酒を貯蔵すると きに増加する色の測定に, $430 \mathrm{~m} \mu$ 附近の吸光度を用い ることが適当であることについてはすでに報告した8)。 清酒の色は，一般にかなり薄いので，これを比色計で測 定するには十分な測定精度が得られるよ5に厚手セルを 用いる必要がある。筆者らは, $50 \mathrm{~mm}$ の七ルを用いて 測定した $430 \mathrm{~m} \mu$ (フィルター）に打ける吸光度で裪変 度を表示することにしている。以下の記述に用いる褐変 度はすべてこの方法で測定した值である。 
清酒を一定温度で夥藏し, 褐変度の変化を追跡すると 上曲りの曲線が得られる。すなわち褐変初期の褐変速度 は比較的小さく一種の誘導期を示すが，褐変の進行とと もに次第に加速されて, 後期には一定の最大速度に近つ き，直線的に褐変が進行するようになる。このような経 過をとる反応の速度を相対的に比較するには，一定の褐 变度（たと壳ば吸光度 $0.5 ）$ 亿達する必要な反応時間 $T$ の逆数值をとるのがもっとも適当と思われるので，この 逆数值 $1 / T$ 学褐变性と呼ぶことにした。この方法でたと

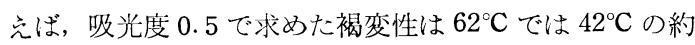
8.8 倍になるのが, 吸光度 0.3 で求めても, また 0.7 で

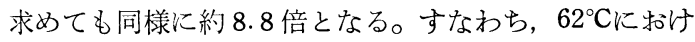
る褐変性は $42^{\circ} \mathrm{C}$ の場合の約 8.8 倍であることを示して いる。

\section{温度による褐変性の変化}

経験的に知られているよ5に, 清酒の褐变性は温度と ともに著しく増加する。清酒 A (普通酒)， G (普通酒)， $\mathrm{H}$ (三增酒) の扮の打のについて褐变曲線を求め, 吸光 度 $0.2,0.3,0.5$ で上述の上万に褐変性 $1 / T\left(\mathrm{day}^{-1}\right)$ を 決めて, この褐変性の対数を温度に対してプロットする と, $30 \sim 100^{\circ} \mathrm{C}$ の範囲で，いずれも同じ匂配をもつ直線 群が得られる。このことは, 清酒の褐変性が各清酒ごと に，温度の指数関係としてきわめて規則的に変化するこ とを示すものである。すなわち, この直線群の匂配か ら，任意の基準貯蔵温度に掓る褐变性を $1 / T_{s}$ この基 準温度から $\Delta t^{\circ}$ だけ温度が変化したときの褐変性を $1 / T$ とするとき，両者の間に(1)式の関倸が成立することが わかる。

$$
1 / T=(1.11)^{\Delta t} \cdot\left(1 / T_{s}\right)
$$

(1)式の関係は温度が 1 度上昇するごとに, 褐変性が 1.11 倍の割合で増加することを示している。この関係 を用いると，予定する貯蔵温度に拈ける褐変経過を実験 的に予測することができるので実用的にもきわめて有用 である。すなわち, 小量の試料清酒(吸光度測定に必要な 量)を数本のアンプルに封入し，これを沸騰水溶中(100 $\left.{ }^{\circ} \mathrm{C}\right)$ に投入し，一定時閒ごとに取出して冷水中に移して 冷却し, その吸光度を測定して $100^{\circ} \mathrm{C} に$ 打ける褐变曲線 を求めれば, あとは $100^{\circ} \mathrm{C}$ と予定貯蔵温度との差 $\Delta t$ か ら (1.11) $)^{\Delta t}$ の值を計算し, この值で時間軸上の単位を 割って換算するだけで，予定貯蔵温度における褐变曲線 が得られる。

\section{pH による褐変性の変化}

褐変反応の多くは $\mathrm{pH}$ とともに反応速度が增加する傾 向がある。清酒に括ける褐変もまた例外でなく, $\mathrm{pH}$ と
ともにその褐变性が増加する。清酒 G, H について, $\mathrm{NaOH}$ または $\mathrm{HCl} て ゙ \mathrm{pH}$ をいろいろに調節し, $100^{\circ} \mathrm{C}$ で褐変性 $1 / T_{0.5}\left(\mathrm{hr}^{-1}\right)$ を測定し，その対数 $\log \left(1 / T_{0.5}\right)$ を $\mathrm{pH}$ に対してプロットすると両者の間には温度変化の 場合と同椂な直線関係がみられる。したがって，(1)式 の場合と同様にこの直線の匂配から，ある基準の $\mathrm{pH}$ か ら $\Delta p H$ だけが $\mathrm{pH}$ 変化した場合の褐変性 $1 / T$ は，もと の褐変性 $1 / T_{s}$ に対して $(2)$ 式の関係にあるということ ができる。

$$
1 / T=(1.55)^{\Delta p H \cdot\left(1 / T_{s}\right)}
$$

( 2 )式に実際に $\mathrm{pH}$ 变化量を代入して褐変性の变化量 をパーセントで求めてみると, 通常清酒にみられる $\mathrm{pH}$ のばらつきの範囲でも，その褐变性におよぼす影響は 10 \%をこえる可能性があることがわかる。

\section{糖濃度による褐変性の変化}

清酒の主成分は, 水とアルコールを除くと, 糖質とア ミノ酸, ペプチドなどのアミノ化合物扣よび有機酸類で ある。この5ち糖質はそのほとんぞがブドウ糖と考学ら れる。この糖含量（普通還元糖であらわされる）は清酒 によってかなりな差異を示すので, 糖含量の褐変性に対 する影響は実用的にも大きな関心がある。

清酒 G（普通酒），H（三増酒）にいろいろな濃度にブ ドウ糖を添加し, その $100^{\circ} \mathrm{C}$ に括ける褐变性 $1 / T_{0.5}$ $\left(\mathrm{hr}^{-1}\right)$ を求めて, これを添加糖濃度に対してプロットす ると, 両者の間に直線関係が認められる。示された還元 糖量を添加糖量軸の負側にとり, 前述の直線との交点を 求めると, このときの縱座標の值はもはや糖濃度には無 関係な褐変性であることになる。すなわち，清酒の褐変 性には，ブドウ糖が関与する反応と，ブドウ糖以外の清 酒成分による褐変の 2 種類の反応が含まれていることを 示している。ブドウ糖の関与しない褐変性は清酒 Gでは 0.39 , 清酒 Hでは 0.40 であって, 抒の拈のの全褐性の 88 抢よび $81 \%$ 飞相当する。すなわち，この清酒の褐変 性のらちブドウ糖の関与する褐变性は 0.055 および 0.092 で全体の 12～19\% 程度にすぎないとい5ことが できる。したがって，たとえば清酒 Gについては，その 褐変性 $1 / T_{0.5}\left(\mathrm{hr}^{-1}\right)$ はブドウ糖濃度 $G(M)$ の一次関数 として (3)式のようにあらわすことができる。

$$
1 / T_{0.5}=0.39+0.42
$$

一方， $1 \mathrm{M}$ ブドウ糖と緩衝液だけを含むモデル系で $\mathrm{pH} 4.22,100^{\circ} \mathrm{C}$ に打ける $T_{0.5}$ を測定すると, $7.7 \mathrm{hr}$ で あって 0.13 の褐変性に相当する。これは一種のカラメ ル化反応であって, ブドウ糖単独の褐变反応と考兵るこ

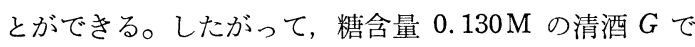
は, $0.13 \times 0.130 \div 0.017$ に相当するカラメル化反応に 
よる褐変性を含んでいることになる。清酒Hではこれが 0.045 となり, 糖含量の高い三增酒ではカラメル化反応 の褐変性に対する割合が大きくなることが認められる。

\section{アミノ化合物濃度による褐変性の变化}

清酒中でブドウ糖につぐ主成分はアミノ化合物（普通 フォルモールNとして測定される）である。この成分は 糖類と反応して褐変することが知られている。いわゆる アミノ・カルボニル反応めるいはメイラード反応であ る。上述のブドウ糖の関与する褐変反応のうち, ブドウ 糖単独のカラメル化反応を除いた残りの褐変性は主とし てこのアミノ・カルボニル反応によるものと考光られ る。すな⿱丶万清酒 Gでは $0.055-0.017=0.038$, 清酒 Hでは $0.092-0.045=0.047$ の褐変性がこれに相当す る。

清酒にグリシンを添加し，グリシン添加量による褐変 性 $1 / T_{0.5}\left(\mathrm{hr}^{-1}\right)$ の変化を $100^{\circ} \mathrm{C}$ で検討したところ, グ リシン添加量と褐变性は，ブドウ糖添加の場合と同様に 直線関係にあることを知った。アミノ酸の種類を变えて も直線の匂配が变わるだけで, 同様に直線関係がみられ る。したがって，アミノ・カルボニル反応による褐変性 は, 糖濃度が一定であれば, アミノ化合物濃度に正比例 することが認められる。そこで, フォルモールNとして 測定される清酒中のアミノ化合物の濃度に関してこの比 例係数を求めてみると, 清酒Gについてはこの反応によ る褐変性 0.038 をア 化合物濃度 $0.029(\mathrm{~N})$ で割り, さらに糖濃度 0.130 (M) で割ることによって，0.038/ $0.0298 / 0.130 \div 9.8$ となる。また清酒Hについては同様 にして 8.85 の值が得られるが, 清酒 $\mathrm{G}$ と同じ $\mathrm{pH} 4.22$ の条件に補正すれば 9.4 となり, 両者の間に実用的な差 異はないと考光られる。そこで, 平均值をとって $\mathrm{pH}$ $4.22,100^{\circ} \mathrm{C}$ の褐变条件では比例定数は実用上一定値 9.6 として取扱うことにした。したがって，アミノ・カ ルボニル反応による褐変性 $1 / T_{0.5}\left(\mathrm{hr}^{-1}\right)$ は, $\mathrm{pH} 4.22$, $100^{\circ} \mathrm{C}$ の条件ではアミノ化合物濃度 $A(\mathrm{~N})$ とブドウ糖 濃度 $G(\mathrm{M})$ の関数として $(4)$ 式のようにあらわされる。

$$
T_{0.5}=9.6 \mathrm{~A} \cdot \mathrm{G}
$$

\section{清酒の褐変性に関係する諸因子の相互関係}

以上飞述べた検討結果から, 清酒の褐变は少なくと も，（1）アミノ・カルボニル反応，（2）カラメル化反 応，(3)ブドウ糖以外の清酒成分による褐変反応の 3 種 類の反応を含んでいるとい方る（1）と（2）の反応は, いずれもブドウ糖が関与する反応で, その褐変性はブド ウ糖濃度に正比例して増加するが，このうち(1)の反応 は,さらにアミノ化合物に関しても正比例して増加す
る。しかし，(3)の反応はブドウ糖やアミノ化合物には 無関係なので, その褐変性は, それぞれの清酒によって 決まる一定值ということになる。したがって，(3), (4)式を総合して, $\mathrm{pH} 4.22,100^{\circ} \mathrm{C}$ の褐変条件では, 清酒の褐変性 $1 / T_{0.5}\left(\mathrm{hr}^{-1}\right)$ は(5) 式であらわすことが できる。

$$
1 / T_{0.5}=h+(0.13+9.6 A) G
$$

ここに $h$ は(3)の反応による褐変性で, (5) 式中この值 だけが清酒によって異なる值である。

この関係はさらに全体として，(2)式で示すように, $\mathrm{pH}$ の变化の影響を受け，また(1)式で示すように貯蔵 温度の影響を受ける。したがって, $\mathrm{pH} 4.22,100^{\circ} \mathrm{C} の$ 褐変条件を計算のための一応の基準として用いると, 任 意の条件に抢ける清酒の褐変性は(6)式の上5に一般化 することができる。

$$
1 / T_{0.5}=(1 \cdot 11)^{\Delta t} \cdot(1.55)^{\Delta p H}\{h+(0.13+9.6 A) G\}
$$

いま，ある組成のわかった清酒が与えられると，その $100^{\circ} \mathrm{C}$ に和ける褐変性 $1 / T_{0.5}$ の值は, 前述の上5 簡単 な方法で実験的に求められる（ $T_{0.5}$ は通常 $2 \sim 3 \mathrm{hr}$ 程度 である)。したがって，決定された褐変性， $\mathrm{pH}$ の 4.22 からのずれ $\Delta p H$, フォルモール N 拉よび還元糖の量を それぞれ(6)式に代入することによって, この清酒に特 有な值 $h$ 求めることができる。こうて ると, 今度は (6)式の関係を用いて, 温度や $\mathrm{pH}$ につい ての任意の貯蔵条件に抢ける褐变性だけでなく, 原酒の 加水や，異なる清酒の混合による組成変化の褐変性汇対 する影響も計算によって容易に見積ることができるよう になる。

\section{清酒における褐変反応の種類と香味熟成の関係}

清酒に和ける香味熟成の処理が常に褐变をともなうと いう経験的事実から, 最適熟度の状態は, 軽微な褐变が 括こっためる一つの状態と考学ることもできる。しか し, 清酒の褐変は単純でなく, 前述したように少なくと も 3 種類の反応を含んでいる。これらの反応が香味に拈 よぼす影響は当然相互に異なるものと考えられる。

色としての寄与はブドウ糖の関与しない（ 3 ）の褐变反 応が压倒的に大さい。しかし，この反応が清酒中のいか なる成分によるものであるかという点については全く不 明で, この反応の香味に掠よ淁す影響についても全く手 掛りがない状態にある一方, (1), (2)の反応は, 色 としての奇与は小さいが，清酒中のブドウ糖の消費をと もな5反応で, 中間体として種々のカルボニル化合物を 生成する。これらのカルボニル化合物については, 直 接, 間接に香味に対する影響の可能性が十分に考兄られ 
るので, 香味の熟成に関してはこの（1)，（2）の両反応 は無視できないい)。

最近アミノ・カルボニル反応の研究が進み, 糖とアミ ノ化合物の相互作用によって, シッフ塩基, アマドリ転 位を介して生成する 3-デオキシグルコソン (3-D-G)が 褐变反応の重要な中間体と考学られるようになってきた 9 14)。3-D-G は結果的にはブドウ糖から 1 分子脱水し て生ずる生成物である。これがさらにも52 分子脱水す るとハイドロオキシメチルフルフラルになる。筆者ら き), 清酒の褐変過程でこの $3-\mathrm{D}-\mathrm{G}$ が生成することを 認めたが，さらに褐変過程に扟ける 3-D-G の消長を解 析して, 褐変による清酒中のブドウ糖の消費のほとんど 全部がこの 3-D-G 経由で行なわれていることを認め さっしかし，3-D-G の生成は，ブドウ糖とアミノ化合 物の相互作用だけでなく, 単純なブドウ糖の脱水反応に らって为扔こること，拈よび 3-D-G のその後の褐変に 快, アミノ化合物との相互作用に上るものもあるが，3D-G 単独の褐変も存在することが同時に認められた。 アミノ化合物の存在で 3-D-G を経由する反応がアミ ノ・カルボニル反応であり, ブドウ糖単独で 3-D-G を 経由する反応がカラメル化反応と考えられる。この両反 态はいずれも 3-D-G を中間体として経由する点では共 通しているが， 3-D-G 以後の反応の内容が巽なるの で，その褐変による生成物もまた異なってくるはずであ ら。このことは, 清酒の種類によって, 雨反応の寄与の 琵度が異なる場合には, 全体としての褐変性は同程度で 方っても，香味変化に対する影響は質的に異なってくる 可能性があることを示している。したがって，上述の （1），（2），（3）の反応门香味に执上ぼす影響を解明し ていくことが今後の問題点ということになる。

\section{清酒におけるその他の褐変}

以上に述べた褐変は，清酒を䀧所で貯蔵するとき常に 钼察される種類の変化で岕って, もっとも基本的な褐変 こいうことができる。しかし, 清酒には, これとは異な る型の褐変が扣こることもある。その5ちで広く知られ ているものとして, 日光など光照射によって拉こる褐変 ぶある。この型の褐変が扔こると清酒の香味が急速沼 化するので実用的にも大きな問題になっている。この型 の褐変経過はかなり速い反応で，乙か子褐変度に一定の 泿度があるという特徵がある(15)。直射日光下では, 数時 間で褐変度が定常状態となる。これに対して, 通常の褐 変汢無限に進行するものであるから, 両者は内容的にも 全く異なる反応ということができる。したがって, 光照 射による褐変は香味の劣化とはしばしば関連づけられる が，熟成と関連づけられることはない。
もら一つの型は, 鉄イオンの混入にょって起こる褐変 である。この褐変は鉄イオンの混入といらかなり, 異常 な事態のもとで起こる褐変であるが, 軽微な場合には香 味に対する影響は明らかでない。最近明らかてされたと ころによれば, これは菞菌の生産する数種の環状ペプチ ドがキレート作用によって鉄イオンと赤色の複合体フェ リクリシン類を形成する結果であるということである17)。 いずれにしてもこの型の褐変は, 混入した鉄イオンの量 と, キレート性環状ペプチドの量によって褐变度が決ま るわけで, 清酒の熟成とは直接的な関係はないと思われ る。清酒の色関しては, 佐藤, 䓹沼らの詳細な総説が ある卢。

\section{むす び}

正常な清酒の場合には, 色が濃いということは, 褐変 反応が進んでいることを意味している。褐变反応が過度 になると, 単衤褐変素が増加するだけでなく, この反 応の副産物が増加して, 過熟という好ましくない香味の 状態になる。しかし, 新酒の香味も, また必ずしも好ま しくないので貯蔵による熟成処理が行なわれている。つ まり, 軽度の褐変が扢こった状態が, いわゆる飲又頃 で，もっとも好ましい香味状態ということができる。し たがって, 清酒の色は, 単に好ましくない香味の指標と してではなく, むしろ熟度の指標として受取るべき性質 のものと考党られる。

しかし, 正常な褐变に打いても, 上述の上うに, 少な くとも 3 種類の内容の異なる反応が， しかもいろいろな 割合で含まれているので, 褐変度と熟度を直接結びつけ ることはできない。また熟成という変化が褐変反応の直 接の結果であるか, または単に平行して進行する相互に 独立な反応でめるかという点についても問題がある。し たがって, これら個々の反応と熟度との関係についての 定量的な検討が今後の問題ということになる。

\section{文献}

1）寺本四郎，小腺 弘: 醉学，12，192，511，674，745（1936）

2) 西川久雄, 传藤 信: 本誌, 53,933 (1958)

3) 風問 雍: 本誌, 60,808 (1965)

4) 岡智, 井出公, 清水俞, 坂井正治: 農化, 39, 415 (1965)

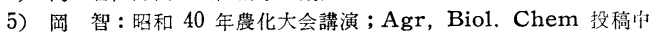

6) 周 智, 立石誠一, 位藤静一: Agr. Biol. Chem 投稿中

7) 阙智: 昭和 42 年酸工大会清酒シンポジウム潇演

8) 岡 智, 大津正記: 農化, 39, 457 (1965)

9) H.Kato: Bull. Agr. Chem. Soc. Japan, 24, 12 (1950)

10) H. Kato: Agr. Biol. Chem., 26, 187 (1962); ibid, 25, 671 (1961)

11) H.Kato: Agr. Biol. Chem., 27, 461 (1963)

12) H.Kato: Agr. Biol. Chsm., 31, 1086 (1967)

13）加蔽博通，桜井䓅人：農化, 36, 131 (1962)

14）加藤㙛通，市畑 均，藤巻正生：農化，37，220 (1963)

15）坂井正治：本誌，60，308 (1965)

16) 传藤信, 整沼 誠: 本誌, 62,1279 (1967)

17) M. Tadenuma, S. Sato: Agr. Biol. Chem., 31, 1482(1967) 